\title{
TRANSPARENCY, ACCOUNTABILITY, AND AUDIT FINDINGS IN BPK RI TO MINIMIZING THE LEVEL OF CORRUPTION
}

\author{
Salwa Nafisah ${ }^{1}$ \\ Dedik Nur Triyanto ${ }^{2}$ \\ Universitas Telkom Bandung \\ salwanafisah@gmail.com
}

\section{A R T I C L E I N F O}

Article history:

Received: 6 July 2019

Revised : 26 July 2019

Accepted : 30 August 2019

Key words:

Transparency, accountability, BPK RI, Audit Findings, Corruption

Level.

DOI:

https://doi.org/10.33508/rima.v2i2.2603

\section{A B S T R A C T}

According to the data from KPK in 2017, the Ministry and Local Government of Indonesia were laced in the $5^{\text {th }}$ rank of biggest number of corruption case in 2017. This study aims to determine the effect of transparency, accountability, and BPK-RI's audit findings in minimalize the level of corruption both partially and simultaneously.

The population of this study was the Ministry and Local Government of Indonesia in 2017. Samples were determined by using purposive sampling analysis which obtained 24 samples data in total. The data analyzed used in this study were descriptive analysis and multiple linear regression. The result of this study showed that transparency, accountability, and BPK RI's audit finding have effect in minimalizing the corruption level.

\section{INTRODUCTION}

In 2017 Transparency International released a corruption perception index of 180 countries in the world. Transparency International concluded that there had not been any progress from these countries to stop Corruption, even if it was mentioned again that the majority of states had produced very little development. From the corruption perception index in the world ranking, New Zealand is in position 1 with a value of 89 , and Somalia occupies the last rank with a 9. At the same time, Indonesia is in place 96, with a value of 37, along with Thailand, Brazil, Panama, Peru, and Zambia (Us, 2018).

On the other hand, in Southeast Asia, Indonesia ranks 4th along with Thailand. Meanwhile, Singapore ranked first, which was ranked 6th globally with a total score of 84, and the last place was Cambodia, which received 161st global rankings of 21 (Transparency International, 2017). The following is a ranking list with the 2017 Corruption Perception Index score:

Tabel 1. Ranking List 2017 Corruption Perception Index

\begin{tabular}{|c|c|c|c|}
\hline $\begin{array}{c}\text { South East Asia } \\
\text { Ranking }\end{array}$ & Global Ranking & Country & Score \\
\hline 1 & 6 & Singapura & 84 \\
\hline 2 & 62 & Malaysia & 47 \\
\hline 3 & 91 & Timor Leste & 38 \\
\hline 4 & 96 & Thailand & 37 \\
\hline 4 & 96 & Indonesia & 37 \\
\hline 5 & 107 & Vietnam & 35 \\
\hline 6 & 111 & Filipina & 34 \\
\hline 7 & 130 & Myanmar & 30 \\
\hline 8 & 135 & Laos & 29 \\
\hline 9 & 161 & Kamboja & 21 \\
\hline
\end{tabular}

Source: www.transparency.org 
Even though Corruption is a global problem, Indonesia shouldn't relax and be proud because, compared to Timor Leste Indonesia's corruption perception index, it ranks behind five digits. When viewed from the corruption perception index last year, Indonesia did not increase or decrease in terms of scores. Still, this score's stability proves that there was no change in efforts to resolve the problem of Corruption in this country.

From the data obtained from the annual report of the Indonesian Corruption Watch, there were 576 trends in handling corruption cases in 2017, and from these cases, there were 1298 suspects that caused state losses of Rp 6.5 Trillion KPK (2017). Compared with the total losses of the previous country, losses in 2017 increased to $100 \%$ of the total value of the former state losses, which amounted to $\mathrm{Rp} 3.085$ trillion (Tempo.co, 2017).

According to the Indonesian Corruption Watch in 2017, Ministries / Institutions and Local Governments occupy the top five positions in the category of most corruption cases based on their institutions, existing data support this. Namely, as many as 42 corruption cases occurred in Ministries / Institutions, resulting in a total state loss of Rp. 2.9 trillion and a total of 373 cases of Corruption that occurred in local governments that harmed the country by approximately $\mathrm{Rp} 1.3$ trillion (Indonesian Corruption Watch, 2017).

Besides the corruption case from the Governor of Bengkulu. Quoted from the news portal News.detik.com (2017), on June 20, 2017, Ridwan Mukti, governor of Bengkulu and his wife, became suspects of Corruption related to the road improvement project in Rejang Lebong Regency. It is suspected that Ridwan promised PT. Statika Mitra Sarana as the project winner. Ridwan received $\mathrm{Rp} .1$ billion from the promised $\mathrm{Rp}$. 4.7 billion.

\section{LITERATURE REVIEW}

Transparency

Based on Government Regulation
No. 71 of 2010, transparency is financial information that is honest and open to the public for consideration because the community has the right to know openly and comprehensively the responsibility of the government in managing the resources entrusted to the government. According to Tahir (2015), transparency is seen in the English language, which means clear and could be seen. Thus transparency is openness in the activity of a government entity. Meanwhile, according to Hamid Muhammad in Latief and Dyah Mutiarin (2014), transparency is the openness of all government policies and actions to create mutual trust between the government and society.

According to Sopanah and Mardiasmo in Khairudin and Rina (2016: 141), five indicators are formulated in determining whether a public sector has implemented transparency;

1. Budget policy announcement is available

2. Budget documents are available and can be accessed

3. Availability of timely accountability report 4 . There is a system of providing information to the public

5. Facilitation of people's proposals.

So from the five indicators, this study uses a scale of 1 to 4 . If it meets the five signs and the difference in one index, means is given a range of 4 , and so on. The more ministry/agency and local government information released on its website, the better the level of transparency is assumed. (Khairuddin and Rina Erlanda, 2016: 147).

\section{Accountability}

According to Starling in Wicaksono (2015), accountability itself is a concept that highlights the ability of public sector organizations to provide answers or take responsibility for actions taken in the political system to interested parties in the organization. Public accountability, according to Mardiasmo in Sitorus (2018: 17), is the obligation of the organization in providing, presenting, and reporting accountability as well as disclosing all 
activities which are the responsibility of the organization to those who have the right and authority to request such accountability.

Accountability of financial statements can be known if an audit has been carried out because the review needs to be done to determine whether the budget given has been used correctly and whether all the budget used has been reported accurately. As explained in Law No. 15 of 2006 concerning the Supreme Audit Board, along with the results of financial audits by BPK-RI on LKPD, accountability can be determined in three categories, namely:

1. Audit Opinion

2. Internal Control System (SPI)

3. Compliance with statutory provisions.

Accountability is assessed using a scale of 5-1, if you get a WTP opinion then a scale five is given if the WTP DPP is given a range of 4 and so on. The opinion is said to be the best when getting WTP opinion, while meant to be the worst when getting TMP opinion.

\section{Audit Findings}

During the audit examination, BPKRI identified conditions where it needed improvement. According to Sawyer in Kusuma (2016), audit findings are deviations from specific criteria, norms, or rules. On the other hand, BPK-RI (2017), explained in the State Financial Auditing Standards that the audit findings are audit findings that contain initial indications of fraud that are presented in the Audit Reports without being described in detail about the type of fraud, and have an influence on the audit findings.

So the audit findings are a condition of the examination where the state is a matter in the form of irregularities and contains an early indication of fraud and influences a situation that will come. So that a problem can be regarded as an audit finding if it meets the five criteria.

According to Huefner in Rini and Damiati (2017), the primary way to prevent fraud is to have a robust internal control system. Besides, according to Feraz and Finan in Rini and Damiati (2017) states that regulations in government can play an essential role in reducing corruption. So that in this study the audit findings can be measured from the number of cases of audit findings of SPI weaknesses and violations of the previous year's law contained in the BPK-RI IHPS report, if the data is not listed in the BPK-RI IHPS report, then the information is not included in the criteria for taking the sample.

\section{Level of Corruption}

According to Law No. 20 of 2001, corruption is an act against the law to enrich oneself or others, resulting in harm to the country or the country's economy because it concerns public money or state assets that are used improperly or not by state law so that when it comes to money or wealth, these crimes can be categorized as theft, robbery, and others.

K / L / PD corruption levels are measured using an Integrity Assessment Survey (SPI) issued by the KPK, with the formula used in determining the level of corruption is 100 - SPI Index.

\section{Research Framework}

\section{Transparency to the Level of Corruption}

Transparency harms the level of corruption because if an entity has carried out maximum transparency, the state apparatus will automatically be reluctant to commit corruption, because transparency will open up everything that is hidden, including if there is a fraud that leads to corruption Khairudin et al. (2016).

\section{Accountability to Corruption Level}

If the results of accountability are excellent and fair, it can be ensured that the public sector has complied with the applicable rules and laws. If the results of proper accountability can be concluded, no fraud or corruption has been detected. So Masyitoh et al. (2015) state that audit opinion has a negative influence on corruption, which means the better the audit opinion received, the lower the potential for corruption.

\section{BPK-RI Audit Findings on Corruption Rates}


According to Sari et al. (2017), the large number of audit findings in the previous period will encourage the government sector to follow up on the audit findings to reduce the audit findings in the next period which results in a high level of disclosure and the probability of getting fewer outcomes in the upcoming period. So if there are many audit findings in the previous year, the level of corruption can be lowered.

\section{Research Hypothesis}

Based on the theory and framework of thinking previously explained, the following research hypotheses can be formulated:

H1: BPK-RI's transparency, accountability, and audit findings simultaneously have a significant effect on the level of corruption in ministries/institutions and local governments surveyed by the KPK in 2017.
H2: Transparency has a significant negative effect on the corruption level in ministries/institutions and local governments surveyed by the KPK in 2017.

H3: Accountability has a significant negative effect on the level of corruption in ministries/institutions and local governments surveyed by the KPK in 2017. H4: BPK-RI audit findings have a significant negative effect on the level of corruption in ministries/institutions and local governments surveyed by the KPK in 2017.

\section{METHODOLOGY}

This type of research is quantitative, with the sampling technique used in this study is purposive sampling. The population in this study is the Ministries / Institutions and Local Governments surveyed by the KPK in 2017 as many as 36 populations. The analytical method used is multiple linear regression using SPSS 25.

Table 2 Criteria Sampling

\begin{tabular}{|c|l|c|c|}
\hline No. & \multicolumn{1}{|c|}{ Criteria } & Total & Accumulation \\
\hline 1. & $\begin{array}{l}\text { Institutions and local government } \\
\text { contained in the results of the KPK } \\
\text { integrity assessment survey in 2017 }\end{array}$ & 36 \\
\hline 2. & $\begin{array}{l}\text { Institutions and local government that do } \\
\text { not include audit opinion data in the BPK } \\
\text { resuls from overview report 2017 }\end{array}$ & $(0)$ & 36 \\
\hline 3. & $\begin{array}{l}\text { Institutions and local governments which } \\
\text { do not include audit findings data in the } \\
\text { BPK result summary report }\end{array}$ & $(12)$ & 24 \\
\hline \multicolumn{2}{|c|}{ Total Sample } & & $\mathbf{2 4}$ \\
\hline
\end{tabular}

Due to the limited amount of data, the number of samples used in the study became 24 samples. According to Supriyanto and Machfudz (2010: 188), this is allowed if the population is small and less than 30 samples.

\section{DISCUSSION}

$\underline{\text { Descriptive Statistics }}$
According to Sugiyono (2014: 206), descriptive statistics are used to analyze data by describing or describing data that has been collected. The results of the descriptive statistical analysis are presented in Table 3 below. 
Table 3. Descriptive Statistics

\begin{tabular}{|l|l|l|l|}
\hline Variable & Mean & Standard Deviation & $\mathrm{N}$ \\
\hline TKOR & 3.4430 & 0.70486 & 24 \\
\hline TRS & 3.0833 & 0.88055 & 24 \\
\hline AKUN & 4.8333 & 0.56466 & 24 \\
\hline TA & 1.9167 & 1.01795 & 24 \\
\hline
\end{tabular}

Source: SPSS

Table 3 shows the mean values for each variable in the level of corruption, transparency, accountability, and BPK-RI audit findings, respectively $3.44,3.08,4.83$, and 1.91 greater than the standard deviation of each variable of $0.70,0.88,0.56$, and 1.01 this indicates that the results of the data in this study are in groups because the standard deviation shows the magnitude of the data deviation, if the standard deviation is greater than the mean, it shows a very high data distribution.

\section{Normality Test}

This test is used to compare the level of suitability of the sample with a particular distribution so that it can be seen whether the compatibility or incompatibility of ordinal data in a delivery.

Table 4. One-Sample Kolmogorov-Smirnov Test

\begin{tabular}{|ll|r|}
\hline & & Unstandardized Residual \\
\hline $\mathrm{N}$ & & 24 \\
Normal Parameters ${ }^{\mathrm{a}, \mathrm{b}}$ & Mean &, 0000000 \\
& Std. Deviation & 4,46680752 \\
Most Extreme Differences & Absolute &, 097 \\
& Positive &, 081 \\
& Negative &,- 097 \\
Test Statistic & &, 118 \\
Asymp. Sig. (2-tailed) & &, $200 \mathrm{c,d}$ \\
\hline
\end{tabular}

Table 4 shows the results of statistical tests using the Kolmogorov-Smirnov model with a significance value of 0.2 , where the number is higher than $a=0.05$. Thus the data has been normally distributed.

\section{$\underline{\text { Multicollinearity Test }}$}

Table 5 Coefficients

\begin{tabular}{|c|c|r|r|}
\hline \multicolumn{2}{|c|}{ Model } & \multicolumn{2}{c|}{ Collinearity Statistics } \\
\cline { 3 - 4 } & & Tolerance & VIF \\
\hline \multirow{4}{*}{1} & (Constant) & & \\
\cline { 2 - 4 } & TRS &, 949 & 1,054 \\
\cline { 2 - 4 } & AKUN &, 883 & 1,132 \\
\cline { 2 - 4 } & TA &, 848 & 1,180 \\
\hline
\end{tabular}

Based on the table above, it can be concluded that this study is free from multicollinearity. This can be seen by comparing the value of tolerance or VIF. From the results of this test the tolerance value of transparency, accountability, and audit finding s $>0.10$, each of them is $0.949,0.883,0.848$ while the VIF values of transparency, accountability, 
and audit findings $<10$ are respectively $1,054,1,132,1.180$ so that it can be concluded that the data have met the classical multicollinearity assumption test.

\section{$\underline{\text { Heteroskedasticity Test }}$}

Table 6. Heteroscedasticity Test Results

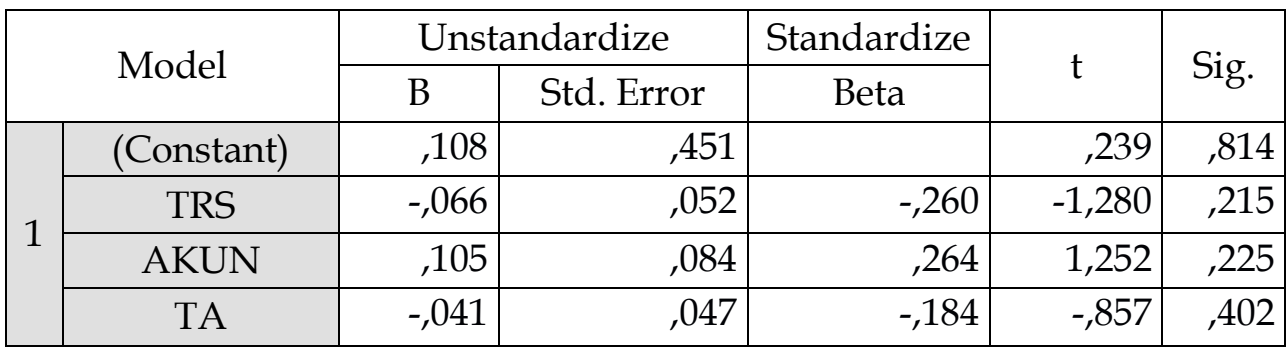

From the glacier test results obtained significance value $\mathrm{X} 1, \mathrm{X} 2, \mathrm{X} 3>0.05$, which is equal to $0.215,0.225,0.402$, it can be concluded that the data has met the standard heteroskedasticity assumption test.

Hypothesis Testing

Coefficient of Determination

Table 7. Model Summary

\begin{tabular}{|c|r|r|r|r|}
\hline $\begin{array}{c}\text { Mode } \\
1\end{array}$ & $\mathrm{R}$ & $\begin{array}{c}\mathrm{R} \\
\text { Square }\end{array}$ & $\begin{array}{c}\text { Adjusted R } \\
\text { Square }\end{array}$ & $\begin{array}{l}\text { Std. Error of } \\
\text { the Estimate }\end{array}$ \\
\hline 1 &, $817 \mathrm{a}$ &, 668 &, 618 &, 43565 \\
\hline
\end{tabular}

The coefficient of determination of $61.80 \%$ can mean that the independent variables consisting of transparency, accountability, and BPK-RI audit findings can explain its influence in minimizing the level of corruption by $61.80 \%$. In comparison, other variables outside this research explain the remaining $38.20 \%$.

\section{$\underline{\text { Test F }}$}

Table 8. F Test Results

\begin{tabular}{|c|c|r|r|r|r|r|}
\hline \multicolumn{2}{|c|}{ Model } & $\begin{array}{c}\text { Sum of } \\
\text { Squares }\end{array}$ & df & Mean Square & F & Sig. \\
\hline \multirow{3}{*}{1} & Regression & 7,631 & 3 & 2,544 & 13,403 &, $000^{\mathrm{b}}$ \\
\cline { 2 - 7 } & Residual & 3,796 & 20 &, 190 & & \\
\cline { 2 - 7 } & Total & 11,427 & 23 & & & \\
\hline
\end{tabular}

$\mathrm{F}$ test results contained in the above variable simultaneously influences the variables indicate a significance value of 0.00 , which is smaller than 0.05 and a calculated $\mathrm{F}$ value of 13.403 , so it can be dependent variable significantly. At the Ministries / Institutions surveyed by the concluded that $\mathrm{Ho}$ is rejected. $\mathrm{Ha}$ is KPK in 2017. accepted, which means that the independent 


\section{$\underline{\text { T-Test }}$}

Table 9. T-Test Results

\begin{tabular}{|c|c|c|c|c|c|c|}
\hline & \multirow[t]{2}{*}{ Model } & \multicolumn{2}{|c|}{$\begin{array}{c}\text { Unstandardized } \\
\text { Coefficients }\end{array}$} & \multirow{2}{*}{$\begin{array}{c}\text { Standardized } \\
\text { Coefficients }\end{array}$} & \multirow[t]{2}{*}{$\mathrm{t}$} & \multirow[t]{2}{*}{ Sig. } \\
\hline & & B & Std. Error & & & \\
\hline \multirow{4}{*}{1} & (Constant) & 7,230 & ,925 & & 7,817 & , 000 \\
\hline & TRS &,- 571 & 106 &,- 713 & $-5,392$ & , 000 \\
\hline & AKUN &,- 363 & 171 &,- 291 & $-2,120$ & , 047 \\
\hline & TA &,- 142 & ,097 &,- 206 & $-1,470$ & 157 \\
\hline
\end{tabular}

The table above shows the results of partial testing or can also be called the T-test; these results can partially explain the independent variable's effect on the dependent variable. Based on table 4.14, it can be concluded that:

a. Sig value of the transparency variable shows the number 0.00 with a coefficient value of -0.571 . This value indicates that 0.00 $<0.05$, it can be concluded that Ho1 is rejected, and Ha1 is accepted, which means that transparency hurts minimizing the level of corruption.

b. Sig value of the accountability variable shows the number 0.047 with a coefficient value of -0.336 . This value indicates that by $0.047<0.05$, it can be concluded that $\mathrm{Ho} 2$ is rejected, and $\mathrm{Ha} 2$ is accepted, which means that accountability has a negative direction in minimizing the level of corruption.

c. Sig value of the audit findings variable shows the number 0.157 with a coefficient value of -0.142 . This value indicates that $0.157>0.05$, it can be concluded that $\mathrm{Ha} 2$ is rejected, and Ho2 is accepted, which means the audit findings do not affect minimizing the level of corruption.

\section{CONCLUSION}

Based on the results of the analysis and discussion, it can be concluded that partially transparency and accountability have a negative and significant effect on corruption. In contrast, the BPK-RI audit findings do not have an impact on minimizing the level of corruption. Simultaneously transparency, accountability, and BPK-RI audit findings affect reducing the level of corruption in Ministries / Institutions and Local Governments surveyed by the KPK in 2017.

\section{$\underline{\text { Suggestions }}$}

a) For further researchers, it is recommended to reexamine variables that have no effect in this study and add other variables such as the audit findings that are followed up and the regional budget. Also, it is advisable to expand the research object and add it to the research period.

b) For the management of Ministries / Institutions and Regional Governments to increase transparency and pay more attention to openness in terms of disclosure of budget documents and accountability documents

\section{REFERENCES}

Fatmawati, N. I. (2017, Juni 21). Kronologi OTT Kasus Suap Gubernur Bengkulu. Dipetik Februari 28, 2019, dari News.detik.com:

https://news.detik.com/berita/d3538058/kronologi-ott-kasus-suapgubernur-bengkulu

Indonesian Corruption Watch. (2017). Laporan Akhir Tahun ICW . Jakarta: antikorupsi.org.

Indonesian Corruption Watch. (2017). Tren Penindakan Korupsi 2017. Jakarta: antikorupsi.org.

Ismunawan. (2016). Pengaruh Faktor non Keuangan dan Keuangan Terhadap Tingkat Korupsi Pemerintah Daerah di Indonesia.Tesis:Fakultas Ekonomi dan Bisnis Universitas Sebelas Maret.

Kami, I. M. (2018, Februari 22). Indeks 
Persepsi Korupsi 2017, Indonesia Peringkat Ke-96. Dipetik Februari 27, 2019, dari news.detik.com: https:/ / news.detik.com/berita/d3879592/indeks-persepsi-korupsi2017-indonesia-peringkat-ke-96

Khairudin dan Erlanda, R. (2016). Pengaruh Transparansi dan Akuntabilitas Laporan Keuangan Pemerintah Daerah (LKPD) terhadap Tingkat Korupsi Pemerintah Daerah (Studi pada Pemerintah Kota Se-Sumatera). Jurnal Akuntansi dan Keuangan, Vol. 7, No. 2 , hal 137-154.

KPK. (2017). Laporan Ilmiah SPI. Dipetik Februari 26, 2019, dari kpk.go.id: https://www.kpk.go.id/id/publikas i/ kajian/671-survei-penilaianintegritas

Kurniawan, Albert. (2014). Metode Riset untuk Ekonomi dan Bisnis: Teori, Konsep, dan Praktik Penelitian Bisnis. Bandung: Alfabeta.

Kusuma, R. (2016). Pengaruh Profesionalisme Auditor Internal dan Role Stress Auditor Internal terhadap Kualitas Rekomendasi Audit Internal. Repository.unpas.ac.id .

Latief, F. d. (2014). Transparansi Pengelolaan Anggaran Daerah di Satuan Kerja Perangkat Daerah (SKPD). Journal of Government UMY (Kajian Manajemen Pemerintahan dan Otonomi Daerah) 2 (1) , 1-19.

Lembaga Administrasi Negara. (2003). Akuntabilitas dan Governance. Dalam L. A. Negara, Modul Sosialisasi Sistem Akuntabilitas Kinerja Instansi Pemerintah (AKIP) (hal. 3). Jakarta.

Pemerintah Indonesia. (2006). UU No. 15 Tahun 2006. Jakarta: Negara Republik Indonesia.

Republik Indonesia. (2001). Peraturan
Pemerintah No. 20 Tahun 2001. Jakarta.

Republik Indonesia. (2010). Peraturan Pemerintah No. 71 Tahun 2010. Jakarta.

Rini, R., Damiati. (2017). Analisis Hasil Audit Pemerintahan dan Tingkat Korupsi Pemerintahan Provinsi di Indonesia. Jurnal Dinamika Akuntansi dan Bisnis Vol. 4(1) , 73 - 90.

Sari, Adelia Pramita. Dwi Martani. Dyah Setyaningrum (2017). Pengaruh Temuan Audit, Tindak Lanjut Hasil Pemeriksaan dan Kualitas Sumber Daya Manusia terhadap Opini Audit melalui Tingkat Pengungkapan Laporan Keuangan Kementerian/Lembaga. Jurnal Universitas Indonesia .

Setiawan, W. (2013). Pengaruh Akuntabilitas Laporan Keuangan Pemerintah Daerah (LKPD) terhadap Tingkat Korupsi Pemerintah Daerah di Indonesia. Universitas Diponogoro .

Sitorus, C. P. (2018). Pengaruh Transparansi dan Akuntabilitas terhadap Tingkat Korupsi. e-Proceeding of Management, 17.

Sugiyono. (2015). Metode Penelitian Pendidikan (Pendekatan Kuantitatif, Kualitatif dan RED) (hal. 13). Bandung: Alfabeta.

Supriyanto, A. S., Machfudz (2010). Metodologi Riset Manajemen Sumber Daya Manusia. Malang: Erlangga.

Tahir, D. A. (2015). Kritik Transparansi dalam Sistem Pemerintahan Daerah. Repository Universitas Negeri Gorontalo

Tempo.co. (2017, Maret 4). Selama 2016, Negara Rugi Rp 3 T dari Kasus Korupsi. Dipetik Februari 27, 2019, dari Nasional.Tempo.Co: https://nasional.tempo.co/read/852 637/sepanjang-2016-negara-rugi-rp- 
3-triliun-dari-kasus-

korupsi $/$ full\&view $=$ ok

Transparency International. (2017).

Corruption Perception Index 2017.

Dipetik Maret 05, 2019, dari Transparency.org:

https://www.transparency.org/new s/feature/corruption_perceptions_in dex_2017

Tuanakotta, T. M. (2010). Akuntansi Forensik dan Audit Investigatif. Jakarta: Salemba Empat.

Wicaksono, K. W. (2015). Akuntabilitas Organisasi Sektor Publik. Jurnal Kebijakan dan Administrasi Publik, Vol. 19, No. 1, ISSN 0852-9213 , 17. 